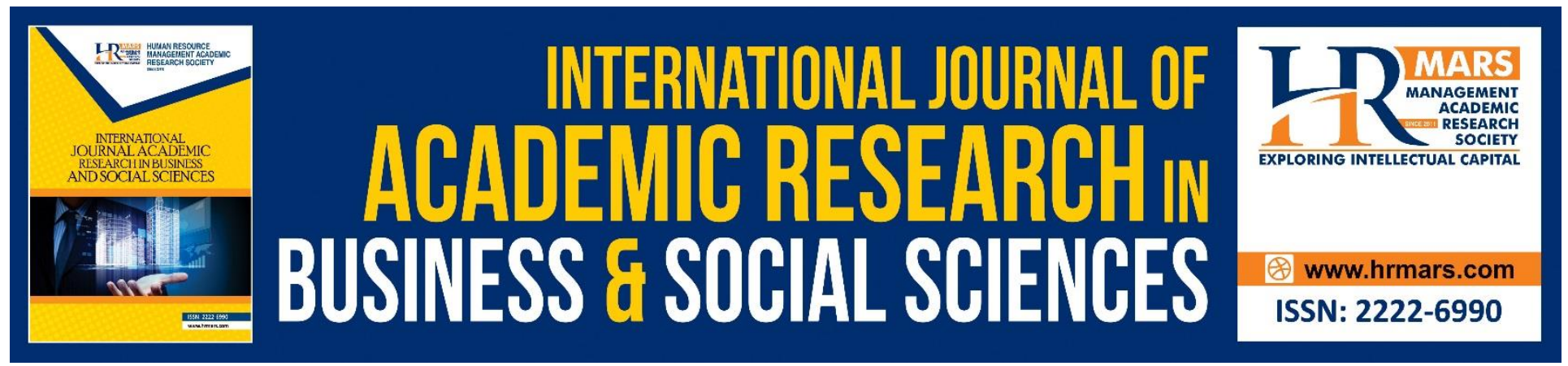

\title{
Dividend Payout and Bonds Risk in Listed Companies from Malaysia
}

Sophee Sulong Balia, Owais Khan and Muhd Abdullah Bin Zaidel

To Link this Article: http://dx.doi.org/10.6007/IJARBSS/v9-i1/5396 $\quad$ DOI: $10.6007 /$ IJARBSS/v9-i1/5396

Received: 22 Dec 2018, Revised: 14 Jan 2019, Accepted: 02 Feb 2019

Published Online: 07 Feb 2019

In-Text Citation: (Balia, Khan, \& Zaidel, 2019)

To Cite this Article: Balia, S. S., Khan, O., \& Zaidel, M. A. Bin. (2019). Dividend Payout and Bonds Risk in Listed Companies from Malaysia. International Journal of Academic Research in Business and Social Sciences, 9(1), 271-283.

Copyright: (C) 2019 The Author(s)

Published by Human Resource Management Academic Research Society (www.hrmars.com) This article is published under the Creative Commons Attribution (CC BY 4.0) license. Anyone may reproduce, distribute, translate and create derivative works of this article (for both commercial and non-commercial purposes), subject to full attribution to the original publication and authors. The full terms of this license may be seen at: $\underline{\text { http://creativecommons.org/licences/by/4.0/legalcode }}$

Vol. 9, No. 1, 2019, Pg. 271 - 283

Full Terms \& Conditions of access and use can be found at http://hrmars.com/index.php/pages/detail/publication-ethics 


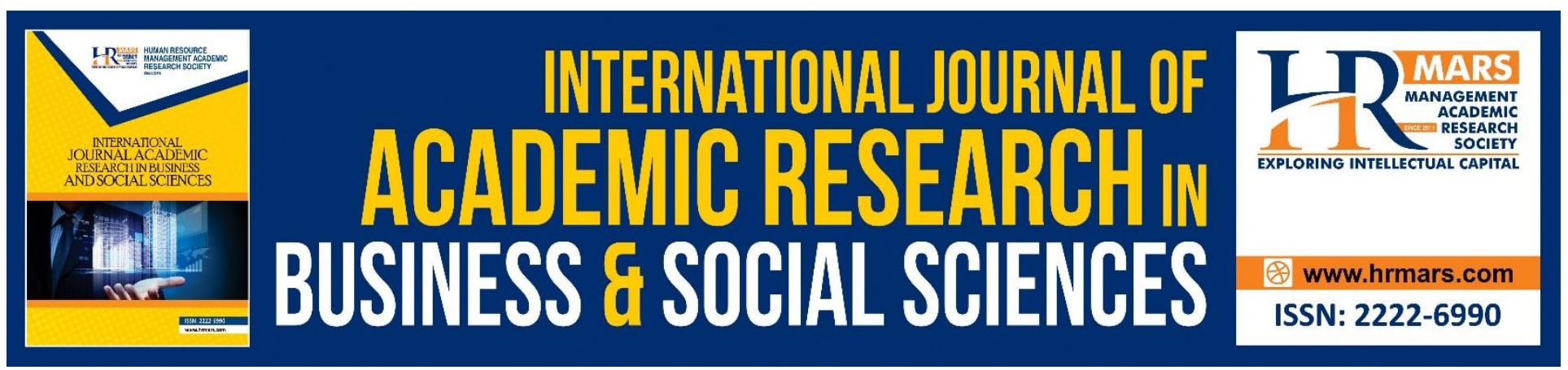

\title{
Dividend Payout and Bonds Risk in Listed Companies from Malaysia
}

\author{
Sophee Sulong Balia, Owais Khan and Muhd Abdullah Bin Zaidel \\ Faculty of Economics and Business, Universiti Malaysia Sarawak (UNIMAS), Malaysia \\ Email: bssulong@unimas.my, owaisuni@gmail.com
}

\begin{abstract}
The study aims to examine the effect of dividend payout on distance to default of bonds issued by non-financial firms listed on Bursa Malaysia. For this purpose, the data is collected of 298 nonfinancial firms over the period 2006-2015. This paper focus on whether Dividend payout (hereafter abbreviate as DPO) is effect on distance to default (hereafter abbreviate as DtD). This study followed the Bharath and Shumway (2008) DtD mixtures model and combining both accounting and marketbased evidence to unravel the Malaysian corporate bonds DtD quality. The results indicated that an increase in dividend payout would results an increase in distance to default (DtD). Further indication on the determinants of DtD is found to be strong to various sensitivity examinations with different trials of variable. Bonds are increasingly playing a more critical role in the private debt intermediation process and are becoming more interconnected with financial system and more significant role in the development of corporate bonds.
\end{abstract}

Keywords: Distance to Default (DtD), dividend payout (DPO), determinants of DtD, Bursa Malaysia

\section{Introduction}

As a developing country, bonds are very important that affect the confidence of financers to invest in Malaysia. Based on Bank Negara Malaysia (BNM) (2018), a complete measurement of corporate area has a great effect on the constancy of an economic system in a country. Based on this report, the bankruptcy cases increased in Malaysia, and credit risk reached to an alarming situation. The rating agency Malaysia released the data of last fifteen years, bonds defaults in Malaysian capital market shows the average of $2.3 \%$ of total bond default in fifteen years. Moody's reports that default rates touched $3.0 \%$ in 2017, in the U.S., 2.54\%, in Europe, and $1.96 \%$ and $0.18 \%$ in the developing markets, which is a "statistical extreme." In the past 30 years, the regular default rate was only $1.2 \%$. Possibly, firms fail to pay their debt due to decrease in cash flows because of dividend payment.

Malaysia is a second biggest dividend payout with in Asia ex-japan. The dividend payout is documented as $48.9 \%$ within the Asia ex-Japan region (Yap, 2012). Besides, the rating authority Malaysia released last fifteen years data on the bonds defaults in capital market. In accordance with 
this report, 5.1 percent, 1.2 percent and 2.6 percent defaults occurred from 2009 to 2011. After 2011, the default percentage reached to less than two percent, but market had not been even completely improved from 2011 to 2015 (MARC, 2015). The bond market has emerged in the market, and regulatory body provides the order and suggestions to the parties involved in Malaysian capital market. Moreover, bond market keeps the businesses away from the banks. Several public indexed companies met escalating difficulties about their performance as well as their profits. Under these conditions, a firm faces difficulty in dividend payment, increases the investor risk aversion and tightens credit conditions that adversely affect the financing.

From 2009 the issuances rate of bonds dropped drown until the end of 2015, the issuances shrink from 98 points to moderate 64 points due to default. It shows that once the bond market was disturbed by defaults, it was unable to get its progress of issuances again. Therefore, it is vital for the firms to be cautious of their potential defaults, since it can severely impact their capital fund raising, and for Malaysian perspective, there are 2.3 percent chances of defaults eruption (MARC, 2015). The reason of this default is that firms issued high yield bonds that led to high cost on those bonds. Moreover, firms are not operating well and the profits are not enough to pay the bonds at maturity. This situation leads the firms to go towards default, as they are unable to meet their obligations (MARC, 2015).

One important element of these defaults is the cost of debt, which creates the conflict between bondholder-shareholder, and this conflict leads to agency problems (Maxwell and Stephens, 2003). Shareholder receives dividends, and bondholder receives the fixed interest payments. These shareholders enjoy the benefits at the expense of bondholders that causes the under investment or over investment problems. Under these circumstances, the bond prices assume to go to the point, where bondholders perceive the expropriation of risk. The more the perceived expropriation risk, the higher is the profit that the bondholders assume on their investment to reward for the extra risk.

Bondholders, shareholders and regulators observe the credit risk management of the firm on their corporate debt performance. In Malaysia, several corporate bonds defaults have brought corporate bonds failure to the forefront of the investment community. On the other hand, conflicting views exist concerning the determining factors of credit risk model. Literature explains that many factors can deteriorate the firms' credit profile leading to the final result of credit default and bankruptcy (Balcaen \& Ooghe, 2006). Hence, it is necessary for the firms to check and improve their credit risk management (RAM, 2015).

High dividend payouts influence the reputation of outside financial investors, as well as lower organization issues and data asymmetries. The high payout ratio alleviates agency conflicts between dividend and credit risk (Farooq \& Jabbouri, 2015; Liu et al., 2017; Zhu et al., 2018). Moreover, the impact of dividend payout on corporate debt remains unclear. This research questions the payout policy related to dividend payments, which significantly affect firm's credit risk and estimate via capital budgeting and corporate financing decisions (Wei et al., 2016; Wei et al., 2017; Devos et al., 2018). Dividends could have a detrimental effect on bondholder wealth, because it eliminates the cash available for debt servicing (Kalay, 1982). Keeping in view the above situation, Malaysian firms are categorized as high dividend paid to the shareholders. 
This study contributes in threefold; first, it examined dividend payout as the factor in the default of the firms listed on Bursa Malaysia. Secondly, it checks the distance to default of Malaysian corporate bonds. Third, this study added dividend payout as a determinant of DtD. Last but not least, this study applied the signaling theory and agency theory to investigate whether or not the signaling theory and agency theory are related to DtD and DPO.

\section{Literature Review}

\section{Signaling Theory}

Dividends may have a signal effect, which helps the organization predict the company's future earnings or long-term planning. Investors expect changes in the company's future earnings outlook based on changes in the amount of dividends. However, compared with the target payout rate, companies should have a stable dividend payout and a higher dividend payout. Dividend changes may not affect the causality of the stock price movement. However, changes in stock prices may reflect future income and opportunity rates. Zameer et al. (2013) observed that due to the distribution of statistical data to the market (Laux, 2011) and the company's future income potential (Zameer et al., 2013), dividends have a signal effect. In other words, dividends are a signaling tool for companies to enter the market.

When corporate management issues securities, traders can expect stock prices to rise. Management uses the additional holding income generated by income to fund the investment. On the contrary, companies increase external financing expenses through debt, indicating that corporate assets are overvalued. This makes investors expect the stock price to fall (Yook, 2003). In the economic market, there are negative statistics on outsiders (shareholders) and insiders (managers and administrators). In this case, managers and directors have additional information on current and future possibilities that outsiders cannot obtain (Malkawi et al., 2010).

The asymmetric information effect of the company's true intrinsic cost cannot be accepted by the market. The stock price is wrong in reflecting the value of the company. In fact, the specific and correct statistics insiders will lead the market and stock prices to respond positively to the bonus statement (Malkawi et al., 2010). This allows traders to think that the dividend announcement is an assessment of the company's future performance and prospects.

The increase in dividend payments means that the company is achieving a satisfactory profit outlook and the stock price will rise. On the contrary, although the reduction in dividends shows the company's bad future and the stock price will eventually fall. By studying the effects of Laux (2011) supporting signals, the payout ratio is higher than the long-term target ratio and an active liquidity shock occurs. Similarly, companies that pay dividends are assumed to have higher income values.

In addition, information on the level of dividends is related to changes in dividends (Grullon et al., 2005). Although changes are not part of future income, changes in the dividend signal do make some changes in current income (Benartzi et al., 1997). Although the distribution of dividends shows an ideal expected result, there is no future profitability development (Grullon et al., 2005).

\section{Agency Theory}

Jensen (1986) introduced agency cost theory which explains the contracting problems of selfinterested individuals having different interests. Jensen (1986) proposed and define agency cost 
theory that "agency cost as a sum of the costs of structuring, bonding, monitoring contracts between agents as well as the costs stemming which it does not pay to enforce all contract perfectly". It highlights the conflict of interest between principal (shareholder) and an agent (manager), where the primary responsibility of the manager is to increase the shareholder wealth and to manage business efficiently (Zameer et al. 2013).

The agency problem arises when manager according to their own interest invest excess cash flows in projects which show negative or low net present value (NPV). Therefore, the shareholders must pay close attention to the manager's functions. The supervisory cost is called the agency cost .Therefore, to reduce the agency cost, dividend is issued which lessen the cash in manger's hand and as a result managers have less or no choice to misuse the funds. Further believe that when the insider increases ownership, the agency cost will decrease. When both the manager and the shareholder adjust their own interests, they do not need to pay dividends to compensate for agency costs.

Waithaka et al. (2012) expressed that one of the major agency problem which result manager and shareholder conflict, which affect the share prices is the availability of free cash flow. Furthermore, results showed that in order to weaken the managerial control over the free cash flow, dividend is the one way to do so. Additionally, agency problem also arise when manager use free cash flow for private benefits, such as investment in negative or low NPV projects, therefore by issuing dividends free cash flow in managers hands can be reduced.

The other side of the coin highlights bondholders and shareholders as another reason for agency cost. Shareholders require high dividend payments whereas bondholders require higher interest and low dividends. The logic behind this is that, debt covenants are provided by bondholders to guarantee cash availability when debt repayment arises. D'Souza (1999) focused on an inverse association between agency cost and dividend payments. Whereas, Holder et al. (1998) concluded that with a rising insider ownership (decrease of agency cost) there would be lower rate of dividend payments.

\section{Methodology}

This study examines 298 firms from non-finance companies and excluded the companies without available data during period from 2006 to 2015. This study employs the panel estimator combined time series and cross sectional data for the empirical test of the hypothesis that can investigate the DtD of the firms. This study ran the diagnostic test before employing the panel model. The purpose of the diagnostic tests to examine DtD and DPO was a statistical test needed to determine the relationship between variables. Hence, in the following investigation, this study implemented a more rich study to those relations with Panel regression model.

\section{Measurement of variables}

In this study included measure DtD; the firm equity; market value of assets; total liabilities; time; return over the previous twelve months and DPO. The following sub-section details the measurement of each of those variables. 


\section{Distance to Default (DtD)}

Our proxy for the default riskiness is a firm's yearly DtD form 2006 to 2015 . Calculation of our DtD is following the bharath and Shumway (2008) method. According to them, the DtD measures the difference between the asset value of the firm and the face value of its debt, scaled by the standard deviation of the firm's asset value. DtD thus measures the number of standard deviation of asset value by which a firm's asset exceeds the face value of its debt.

$$
D t D_{\text {naive }}=\frac{\ln (M T A / T L)+\left(E R 1 y-0.5 \sigma_{A, \text { naive }}^{2}\right) T}{\sigma_{A, \text { naive }} \sqrt{T}}
$$

Hillegeist et al, (2004) proposed the importance of asset volatility while financial probability of firm is calculated. The reason is that, it takes in to account the chances of decreasing firm asset's market value below its debt's face value. DUffie, Saita, and Wang (2007) spotted that conditional probabilities of defaults return structure emerged from data related to bankruptcy highly relies on DtD of firm. Furthermore, the financial distress probability can be calculated by using DtD as the proxy since a support is offered by these studies.

\section{Leverage}

Companies extremely leverages are perceived to have greater credit default risk (Cheng \& Subramanyam, 2008) which may perhaps impact DtD levels. Debt and equity proportion has been commonly used previous finance literature to assume leverage. Thus debt to equity proportion is the traditional measure of a company's financial risk. It measures the ratio of its equity by interestbearing responsibilities, which is used to finance its assets. If the income before interest and tax (EBIT) reduces, a firm goes the risk of default on its debt responsibilities. Increased leverage decreases earning by presenting higher equity and default risks (Kia, 2002; Kim, 2005).

The trade-off theory of capital structure suggests that the firm chooses an optimal ratio of its debt to asset value by determining the ratio of debt and equity, which is used to finance its action in order to bring equilibrium in cost and benefits. An optimal leverage proportion implies that a firm adjusts its unpaid debt in answer to change in its asset value in order to reach a target level of its leverage proportion (Titman \& Tsyplakov, 2007).

Therefore, in our correction, this study describe leverage proportion as total debt divided by the total shareholder equity of the firm.

Leverage $=$ Total Debt $/$ Total Shareholder Equity

Here, total debt represents totally interest bearing and capitalizes lease responsibilities. It is the sum of long and short term debt. Similarly, total shareholder' equity represent the sum of preferred stock and common shareholder' equity. This item is collected based on the yearly time series.

\section{Equity Beta}

Asset volatility is not directly observable. In a simplified framework, asset volatility should be proportional to equity volatility (Campbell and taskler, 2003). The firm's equity volatility in our study is calculated using each firm daily closing price return over the period of one year from 2005 to 2015.

The effect of using equity market price volatility on asset the DtD is that it addresses the appropriateness of information used in assessing firm's financial health. Equity price are also the consensus view from the public market which ideally would be a cumulative of all the available 
information about a firm. Thus, equity volatility could be considered a robust observation of the firm's credit riskiness that also responds more quickly to events leading to increases in the firm's risk of default.

In empirical literatures on the determinants of corporate bond spreads, Campbell and Taksler (2003) perform an analysis on corporate bond credit risk and conclude that firm specific equity volatility is an important determinant of the corporate bond spreads and that the economic effects of volatility are large. Cremers et al. (2008) using volatility implied by individual equity, confirmed Campbell and Taksler (2003) result they (2008) argue that equity volatility also contains information, which are useful for analysis different form historical volatility.

From previous experimental findings, it is therefore, assumed that equity beta indicate the tendency of a security return to respond to volatility in market return.

Where:

$$
e_{\beta}=\sqrt{\frac{1}{N}} \sum_{i=1}^{n}(x i-\mu) 2
$$

$e_{\beta}=$ equity volatility

$\mu=$ mean of all values

$x^{2}=$ individual value of $\mathrm{x}$

$\mathrm{N}=$ number of observations

In this study it is planned that the $e \beta$ takes useful evidence for predicting DD level. Market price and return should incorporate the risk contact of the firm and thus their complete default risks. The higher is e $\beta$, the more liable the firm is to the economy-wide macro-systemic risk and the lesser is it DtD (the $D t D$ is expected to be negatively related to e $\beta$.

\section{Market to Book Value (mtb)}

High economic growth ratio implies high total firm growth ratio. A firm is fewer probable to go into default when it grows fasters. The market to book value follow Ceccagnoli (2009) and Lee and Makhija (2009) who proxy growth as the market to book ratio (mtb). This measure has also been extensively used in previous studies (Kim, 2005; Shangguan, 2007). The mtb proportion is found to be an attractive measure of growth primarily because $\mathrm{mtb}$ proportion basically indicates the difference between the net assets of the firm and the estimation that the market gives to them.

Simply, the mtb ratio reflects the premium or (discount) that the market gives to the firm on its net assets and therefore, this reflects the efficiency with which the market views the firm as being managed. High mtb ratio suggests that for every additional Ringgit invested in the net assets of the firm, it would yield an attractive return for the investors. Conversely, a low mtb ratio means that the returns on additional investments are $u$ unlikely to be attractive, as such; the mtb ratio reflects the incentives for additional capital investments help the fiem to grow (Goranova, Dharwadkar, \& Brandes, 2010). Therefore $\mathrm{mtb}$ is indicative not only of future growth potential but also linked to risk (Griffin \& Lemmon, 2002).

In more recent study, Shangguan (2007) provides evidence that earnings growth measured by $\mathrm{mtb}$ ratio is appositive and significant determinant in the presence of illiquid growth opportunities. Since the mtb ratio incorporate both historical and forward looking market indicators of firm 
performance, it provide a theoretical rationale for using the mtb ratio as a measure of growth performance (Lee \& Makhija,2009) and this study propose that it should also affect DtD. This study also calculate the $\mathrm{mtb}$ ratio as the market value of equity divided by the book value of common shareholder equity following approach adopted by Anderson et al (2003). In this study, the mtb is represented as follows,

$$
M T B=\frac{M V E_{i t}}{B V E_{i t}}
$$

Where:

MVE = Market Value of Equity

$\mathrm{BE}=$ Book Value of Equity

Where, market value of equity (MVE) is the product of closing shares price ( $p$ ) and the number of shares, in other words, the stock market capitalization. Book value of equity represents the shareholder equity i.e. the difference' of total assets and total liabilities.

\section{DPO}

To estimate numerically, changes in the cost of debt in accordance with dividend distribution Becker et al (2011) conducted a study. His study took dividend yield as a proxy measure to payout. The dividend yield is considered as RM quantity of annual dividend payment to the issuance of debt dividend by the ending monthly price closer to the data of issuance.

\section{Result and Discussion}

$$
\text { Div Pout }_{i t}=\left(\frac{\sum \text { Annual Dividend }_{i t}}{{\text { Share } \text { Price }_{i t}}_{\text {in }}}\right)
$$

Table 0.1: Descriptive statistics

\begin{tabular}{ccccc}
\hline Variable & Mean & Std. Dev & Min & Max \\
\hline DtD & 2.36 & 1.52 & 0.21 & 10.35 \\
DPO & 18.22 & 23.21 & 0 & 95.92 \\
& & & & \\
\hline
\end{tabular}

$\mathrm{N}=2682 ; \mathrm{n}=298 ; \mathrm{T}=9$

Table 4.1 shows the two main variables in the descriptive statistics such as DtD and DPO. As shows in the table, the mean of the ratio of DtD is 2.36.The range between minimum and maximum value is 0.21 and 10.35 and the standard deviation is 1.52 . The mean of the DPO is 18.22 , minimum and maximum value is 0 and 95.92 and the standard deviation is 23.21. The detail year wise explanation of mean value, standard deviation, minimum and maximum value of distance to default (DtD) in Table 4.1. 
INTERNATIONAL JOURNAL OF ACADEMIC RESEARCH IN BUSINESS AND SOCIAL SCIENCES

Vol. 9, No. 1, Jan, 2019, E-ISSN: $2222-6990$ @ 2019 HRMARS

Table 0.2: Correlation Analysis

\begin{tabular}{llllll}
\hline DtD & DtD & DPO & $m t b$ & lev & $e b$ \\
\hline DtD & 1.0000 & & & & \\
DPO & 0.2139 & 1.0000 & & & \\
$m t b$ & 0.0863 & 0.1421 & 1.0000 & & \\
lev & -0.1806 & 0.0886 & 0.1035 & 1.0000 & \\
$e b$ & 0.0437 & 0.0484 & -0.0077 & 0.0556 & 1.0000 \\
\hline
\end{tabular}

Table 4.2 shows the correlation matrix for all variables. The correlation matrix shows the direction of relationship between the variables. Dividend payout has a positive correlation value of 0.2139 with distance to default (DtD). This relationship shows that when the dividends pay-out level increase the bonds default increases and the result is same as Bharath and Shumway (2008) distance to default method measure. Market to book value $(m t b)$ has a positive correlation as 0.0863 with DtD. Leverage has a negative correlation value of -0.1806 with DtD. Equity beta has a positive correlation effect with DtD at a value of 0.0437 . Equity Beta has effect $4.37 \%$ of DtD.

Table 0.3: Results of Panel Data Analysis, Dependent variable and Independent variable

\begin{tabular}{lc}
\hline \multicolumn{2}{c}{ Model DPO } \\
\hline DtD & 0.013 \\
& $(0.001)^{* * *}$ \\
Lev & -0.131 \\
& $(0.035)^{* * *}$ \\
Mtb & -0.113 \\
& $(0.022)^{* * *}$ \\
E6 & 0.790 \\
& $(0.319)^{* *}$ \\
Cons & 1.796 \\
& $(0.200)^{* * *}$ \\
\hline Observations & 2682 \\
\hline Multicollinearity & 1.02 \\
Heteroskedasticity & $7.1 \mathrm{e}+05$ \\
(x - stat) & $(0.0000)^{* * *}$ \\
Autocorrelation & 86.115 \\
& $(0.0000)^{* * *}$ \\
\hline
\end{tabular}

Table 4.3 shows the complete detail of the model DPO, there is no any heteroskedasticity and autocorrelation problem in this study. All the variables are significant with DPO. The result of the main dependent variables which is DtD can clarify that increase in firm DPO will results in the increase of default. A large dividend payout signifies management's confidence in the future cash flows of the firm. These imply that one unit increase in DPO will cause a 0.013 rises in the DtD accordingly. This relationship is consistent with the signaling theory that explains firm with higher dividend payout; is 
more causing dividend default. From the table, the important effects remain significant and the empirical result is highly consistent with our previous findings.

Guntay and Hackbarth (2010) was documented that the Malaysia corporate bonds continuously default from 2005 to 2015 and the default ratio is 2.3\%. Furthermore, Malaysia continuously pays dividends to their shareholder and become the second high paid dividend country in the Asia with ex-japan. Guntay and Hackbarth (2010) also mentioned that the outcome of the dividend payouts and DtD is expected to be negative. The correlation analysis shows that the dividend payout and distance to default have a positive relationship. DtD nearer to zero indicates a firm closer to default whereas a firm having DtD far from zero indicates high chances to default. This study is similar with Bharath and Shumway (2008), they mentioned that distance to default method in Malaysia are still 2.35 far from the default. It shows that increase in dividend payouts will slightly increase the bonds default. Therefore, this result shows the significant and positive relationship between dividend payout and distance to default. It is consistent with Singh and Nejadmalayeri (2004); Bharath and Shumway (2008). This result indicates that somehow dividend payouts affect Malaysia bonds.

The signalling theory suggests that bondholders view huge dividend payouts as a positive signal and result require a lower rate of return. In contrast, agency theory noted that dividends denote as a wealth re-distribution from bondholders to shareholders and, therefore, are viewed negatively by bondholders. Hence, this study found the significant results are relevant to the signalling theory but not relevant with agency theory. This also implies that at lower levels of dividend payouts, bond investors interpret dividend distributions as a positive signal about the future prospect of the firm.

\section{Conclusion}

The results of this study found that there is a significant and positive relationship between dividend pay-outs and distance to default (DtD) and result of correlation analysis shows that dividend payout have a positive effect on Malaysia bonds. The result is consistent with Singh and Nejadmalayeri (2004); Bharath and Shumway (2008) distance to default calculation shows that Malaysia bonds are still far from default. Furthermore, the regression parameter significant and positive result shows that somehow dividend payouts affect Malaysia bonds.

Future researchers may use different approaches of operationalizing the DtD, and different methods that may produce different outcomes in the Malaysian context. This study can be further explore in the other country. Future researchers may cover their analysis to include more listed and public companies in Malaysia in their research samples. To this extent, a relative analysis of public listed companies and private companies could be carried out. Also, future researches should study other industries such as finance, hotels, mining, IPC, REITs and SPAC sector as well as banking independently or as whole. Finally, future institutional setting should involve IT-based manager or IT based director to provide internet reporting-related discovery for large samples with minimum time and effort.

The signaling hypothesis proposes that bondholders view large dividend pay-outs as a positive indication and as a result need a lower rate of return. In specific, at lower levels of pay-outs, bond investors understand dividend supplies as a positive signal about the greater future prospect of 
INTERNATIONAL JOURNAL OF ACADEMIC RESEARCH IN BUSINESS AND SOCIAL SCIENCES

Vol. 9, No. 1, Jan, 2019, E-ISSN: 2222-6990 (C) 2019 HRMARS

the firm and therefore require a lower return. Through contrast, when dividend payouts reach higher levels, bond investors regard huge cash distributions as detrimental to their attention, and therefore, demand a higher return. This leads to higher default of debt for firms. Thus, the findings of this research found the significant results are relevant to the signaling theory.

\section{References}

Balcaen, S., \& Ooghe, H. (2006). 35 years of studies on business failure: an overview of the classic statistical methodologies and their related problems. The British Accounting Review, 38(1), 6393.

Bank Negara Malaysia (2018) Retrieved from http://www.bnm.gov.my/

Becker, B., Ivković, Z., \& Weisbenner, S. (2011). Local dividend clienteles. The Journal of Finance, 66(2), 655-683.

Benartzi, S., Michaely, R., \& Thaler, R. (1997). Do changes in dividends signal the future or the past? The Journal of Finance, 52(3), 1007-1034.

Campbell, J. Y., \& Taksler, G. B. (2003). Equity volatility and corporate bond yields. The Journal of Finance, 58(6), 2321-2350.

Ceccagnoli, M. (2009). Appropriability, preemption, and firm performance. Strategic Management Journal, 30(1), 81-98.

Cheng, M., \& Subramanyam, K. R. (2008). Analyst following and credit ratings. Contemporary Accounting Research, 25(4), 1007-1044.

Cremers, M., Driessen, J., Maenhout, P., \& Weinbaum, D. (2008). Individual stock-option prices and credit spreads. Journal of Banking \& Finance, 32(12), 2706-2715.

D’souza, J., \& Saxena, A. K. (1999). Agency cost, market risk, investment opportunities and dividend policy-an international perspective. Managerial Finance, 25(6), 35-43.

Devos, E., Islam, M. N., \& Rahman, S. (2018). Financial Statement Comparability and Corporate Dividend Payout Policy. Retrieved from http://fmaconferences.org/SanDiego /Papers/Financial_Statement_Comparability_and_Corporate_Dividend_Payout_PolicyFMA.pdf

Duffie, D., Saita, L., \& Wang, K. (2007). Multi-period corporate default prediction with stochastic covariates. Journal of Financial Economics, 83(3), 635-665.

Farooq, O., \& Jabbouri, I. (2015). Cost of Debt And Dividend Policy: Evidence From The MENA Region. Journal of Applied Business Research, 31(5), 1637-1651.

Goranova, M., Dharwadkar, R., \& Brandes, P. (2010). Owners on both sides of the deal: mergers and acquisitions and overlapping institutional ownership. Strategic Management Journal, 31(10), 1114-1135.

Griffin, J. M., \& Lemmon, M. L. (2002). Book-to-market equity, distress risk, and stock returns. The Journal of Finance, 57(5), 2317-2336.

Grullon, G., \& Michaely, R. (2005). Dividends, share repurchases, and the substitution hypothesis. The Journal of Finance, 57(4), 1649-1684.

Güntay, L., \& Hackbarth, D. (2010). Corporate bond credit spreads and forecast dispersion. Journal of Banking \& Finance, 34(10), 2328-2345. 
INTERNATIONAL JOURNAL OF ACADEMIC RESEARCH IN BUSINESS AND SOCIAL SCIENCES

Vol. 9, No. 1, Jan, 2019, E-ISSN: 2222-6990 @ 2019 HRMARS

Hillegeist, S. A., Keating, E. K., Cram, D. P., \& Lundstedt, K. G. (2004). Assessing the probability of bankruptcy. Review of Accounting Studies, 9(1), 5-34.

Holder, M. E., Langrehr, F. W., \& Hexter, J. L. (1998). Dividend policy determinants: An investigation of the influences of stakeholder theory. Financial Management, 73-82. Retrieved from http://global.britannica.com/EBchecked/topic/471865/pos itivism

Jensen, M. C. (1986). Agency costs of free cash flow, corporate finance, and takeovers. The American Economic Review, 76(2), 323-329.

Kalay, A. (1982). Stockholder-bondholder conflict and dividend constraints. Journal of Financial Economics, 10(2), 211-233.

Kia, M., Shayan, E., \& Ghotb, F. (2002). Investigation of port capacity under a new approach by computer simulation. Computers \& Industrial Engineering, 42(2), 533-540.

Kim, Durnev, A. \& E. H. A. N. (2005). To steal or not to steal: Firm attributes, legal environment, and valuation. The Journal of Finance, 60(3), 1461-1493.

Laux, J. A. (2011). Topics in Finance, Part VII: Dividend Policy. (Colorado College Working Paper No. 2011-05). Retrieved from http://dx.doi.org/10.2139/ssrn.1885167

Lee, S. H., \& Makhija, M. (2009). Flexibility in internationalization: is it valuable during an economic crisis?. Strategic Management Journal, 30(5), 537-555.

Liu, B., Xu, Q., Yang, J., \& Zhang, S. (2017). Liquidity default, liquidity management and smooth dividends policy. Applied Economics, 49(56), 5728-5739.

Malkawi, H. A. N., Rafferty, M., \& Pillai, R. (2010). Dividend policy: A review of theories and empirical evidence. International Bulletin of Business Administration, 9(1), 171-200.

Mathur, I., Singh, M., Nejadmalayeri, A., \& Jiraporn, P. (2013). How do bond investors perceive dividend payouts? Research in International Business and Finance, 27(1), 92-105.

Maxwell, W. F., \& Stephens, C. P. (2003). The wealth effects of repurchases on bondholders. The Journal of Finance, 58(2), 895-919.

Ram (2015) Rating Agency Malaysia Berhad. Retrieved from https://www.ram.com.my/

Shangguan, Z. (2007). Risky debt and the earnings response coefficient: a reexamination in the presence of illiquid growth opportunities. International Journal of Business Innovation and Research, 1(4), 404-424.

Singh, M., \& Nejadmalayeri, A. (2004). Internationalization, capital structure, and cost of capital: evidence from French corporations. Journal of Multinational Financial Management, 14(2), 153-169.

Titman, S., \& Tsyplakov, S. (2007). A dynamic model of optimal capital structure. Review of Finance, 11(3), 401-451.

Waithaka, S. M., Ngugi, J. K., \& Kirago, P. (2012). Effects of dividend policy on share prices: A case of Companies in Nairobi Securities Exchange. Prime Journal of Business Administration and Management (BAM), 2(8), 23-48.

Wei, Truong, \& Do, V. M. (2017). Unexpected Dividend Change Announcements and Corporate Bond Price Reactions. 29th Australasian Finance and Banking Conference 2016. Retrieved from http://dx.doi.org/10.2139/ssrn.2826566

Yap, J. (2012). Malaysia among the highest in dividend. Retrieved from Borneo Post online http://www.theborneopost.com 
Yook, K. C. (2003). Larger return to cash acquisitions: Signaling effect or leverage effect? The Journal of Business, 76(3), 477-498.

Zameer, H., Rasool, S., Iqbal, S., \& Arshad, U. (2013). Determinants of Dividend Policy: A case of banking sector in Pakistan. Middle-East Journal of Scientific Research, 18(3), 410-424.

Zhu, M., Chen, R., Du, K., \& Wang, Y. G. (2018). Dividend growth and equity premium predictability. International Review of Economics \& Finance, 6(3), 125-137. 